\title{
Compensation Method for Fluctuation Power of Wind Power Generation Using Biomass Gas Turbine Generator and Flywheel Energy Storage Equipment
}

\author{
Masahiko Hara Student Member (Mie Univercity, hara@cs.elec.mie-u.ac.jp) \\ Naoki Yamamura Member (Mie Univercity, yamamura@elec.mie-u.ac.jp) \\ Muneaki Ishida Member (Mie Univercity, ishida@elec.mie-u.ac.jp) \\ Masaaki Wakita Non-Member (Mie Univercity, wakita@bio.mie-u.ac.jp) \\ Yasunari Kamada Non-Member (Mie Univercity, kamada@mach.mie-u.ac.jp) \\ Takao Maeda Non-Member (Mie Univercity, maeda@mach.mie-u.ac.jp)
}

Keywords: wind power generation, flywheel energy storage equipment, biomass generation, power compensation, power capacity

\section{Introduction}

Recently, electiric power generation using natural energy and biomass energy are getting much attention. But, the generated power using natural energy depends on weather condition. So, it contains big fluctuation. Therefore, the system to compensate such a power fluctuation is necessary for practical use. Energy storage equipment is used as a method of power compensation. Therefore, when it compensates for all power fluctuation generated from such a system only by energy storage equipment, it should have large capacity. Consequently, we have an interest in biomass generation system that usually operates alone. And we propose the power compensating method for the low frequency fluctuation using that system. In the system design, the capacity of the energy storage equipment can be decreased by using this method. Therefore, by the natural energy generation system become widely using the proposed method. In proposal system, we show results of demonstration experiment to prove effectiveness.

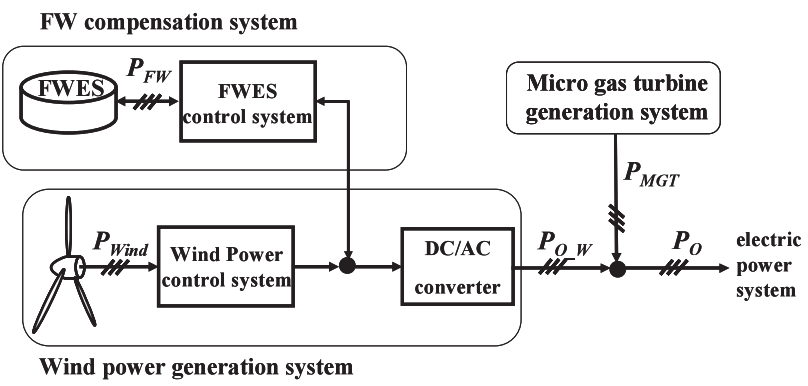

Fig. 1. Compound type natural energy generation system

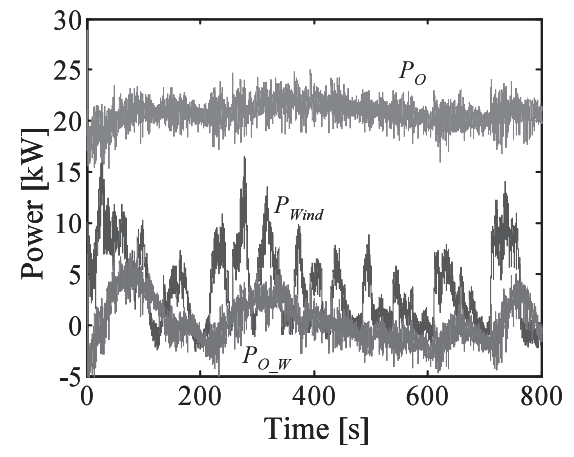

Fig. 2. Result of compensation power

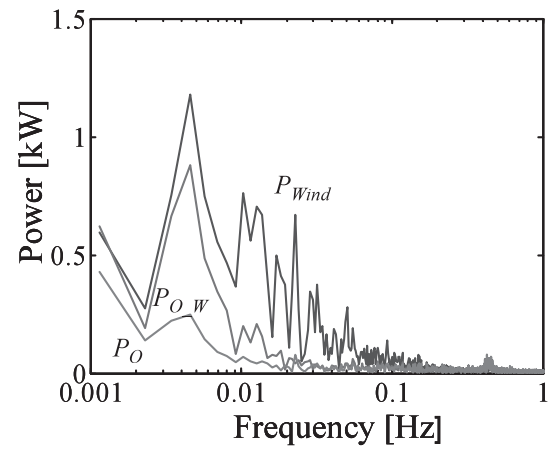

Fig. 3. Frequency analysis

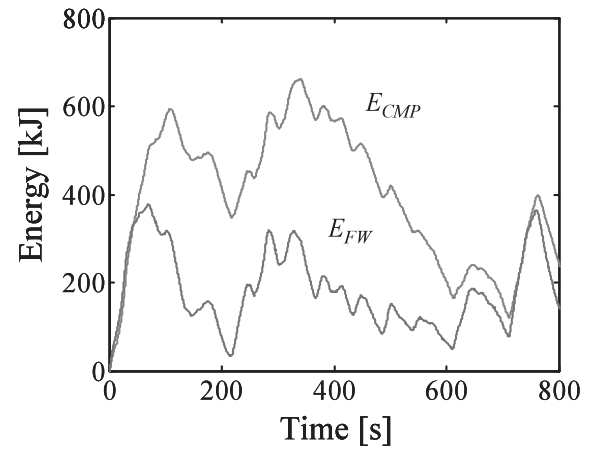

Fig. 4. Compensated energy 


\title{
バイオマスガスタービン発電機とフライホイール電力貯蔵装置を 用いた風力発電の変動電力補償法
}

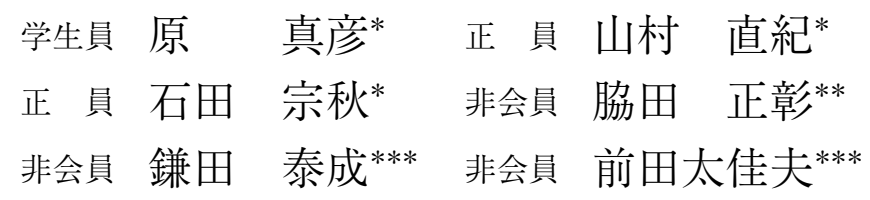

\section{Compensation Method for Fluctuation Power of Wind Power Generation Using Biomass Gas Turbine Generator and Flywheel Energy Storage Equipment}

\author{
Masahiko Hara*, Student Member, Naoki Yamamura*, Member, Muneaki Ishida*, Member, \\ Masaaki Wakita**, Non-member, Yasunari Kamada***, Non-member, Takao Maeda***, Non-member
}

\begin{abstract}
The power generation using natural energy contains electric power fluctuation. Therefore, in order to put such power generation system to practical use, compensation for system power fluctuation is needed. In this paper, we propose a power compensation method using biomass gas turbine generator and flywheel energy storage equipment. The gas turbine generator is used for compensation of low frequency power fluctuation in order to decrease capacity of flywheel. Usefulness of the proposed system is confirmed by experiment using a test plant.
\end{abstract}

キーワード : 風力発電, フライホイール電力貯蔵装置, バイオマス発電, 電力平準化, 電力容量

Keywords: wind power generation, flywheel energy storage equipment, biomass generation, power compensation, power capacity

\section{1. はじめに}

現在，まとまって捨てられる，あるいは放置されている バイオマスは全国に多数あると考えられる。これらを放置 しておくと, $\mathrm{CO}_{2}$ よりはるかに地球温暖化効果が強いメ夕 ンが発生する。そこでこのメタンを利用し, 発電を行なう ことで，温暖化を防止すると共に化石燃料の消費を削減す ることが可能となる。そのため，バイオマスを用いた発電 システムが注目されている。

バイオマスが発生する，あるいは存在する場所に適した 規模の発電・資源再利用システムを構築し事業として成り 立つためには，バイオマス収集コストを考慮し，バイオマ スを発生する事業所単位で, 数十 $\mathrm{kW}$ 程度の比較的小規模 の発電システムを想定したほうが望ましい。しかしながら，

* 三重大学工学研究科電気電子工学専攻

于 514-8507 津市栗真町屋町 1577

Department of Electrical and Electronics Engineering, Mie University 1577, Kurimamachiya, Tsu 514-8507

** 三重大学生物資源学研究科生物圈生命科学専攻

₹ 514-8507 津市栗真町屋町 1577

Department of Biosphere life Engineering, Mie University 1577, Kurimamachiya, Tsu 514-8507

*** 三重大学工学研究科機械工学専攻

T 514-8507 津市栗真町屋町 1577

Department of Mechanical Engineering, Mie University 1577, Kurimamachiya, Tsu 514-8507
バイオマスだけで数十 $\mathrm{kW}$ 程度の電力を発電しようと考え ると, 供給エネルギーが不足する。このことからエネルギー 的に自立するためには自然エネルギーを複合する方法が考 えられる。しかし, 自然エネルギーを利用した発電システ ムは, 従来の化石燃料を用いた発電システムとは異なり, 発電される電力は季節や気象条件などに大きく依存するた め変動が生じる。そのため, バイオマス発電に自然エネル ギー発電を複合した場合, 現在の電力系統と同等の電力品 質を維持するためには, この変動電力を平準化するシステ ムが必要である。そこで, フライホイール電力貯蔵装置や 二次電池といった電力貯蔵装置を用いる手法が多く提案さ れている(2)(3)。しかし, 電力貯蔵装置のみで自然エネルギー 発電システムから発電される変動電力の低周波変動を補償 するためには大きな容量を持った電力貯蔵装置が必要とな る。そこで本研究では, 一般に定出力で運転される(4) バイ オマスガスタービン発電を自然エネルギー発電システムに よる低周波変動電力を補償することを提案する。このよう なシステム構成とすることで, 自然エネルギー発電システ ムとバイオマス発電を複合する際に使用する電力貯蔵装置 の容量を低減することが可能である。

本研究ではバイオマスを用いた発電システムとして, 畜 粪や廃乳から得られるバイオマスガスを利用し発電するマ イクロガスタービン (MGT) 発電機を用い, 自然エネルギー を用いた発電システムとして風力発電を用いる。そして, 
電力貯蔵の手段として電気的に優れた応答性を有し, 堅牢 といった特徴を持ち，二次電池に比ベリサイクルが容易で あり, 化学廃棄物も少なく, 対環境性に優れるといった利点 を持つ，フライホイール電力貯蔵装置（FWES：FlyWheel Energy Storage equipment）により構成される複合型自然エ ネルギー発電システムを提案し, 高品質な電力を供給する ことを目的とする。本論文では, 電力平準化を行う上で, 風 車の発電電力の周波数分布や MGT 発電機及び FWES の補 償能力を考慮した電力補償法について述べ，これを用いた 実証試験結果により提案システムの有効性を検証する。

\section{2. 複合型自然エネルギー発電システム}

提案する複合型自然エネルギー発電システムを Fig. 1 に 示す。本システムは, 本学の三重大学フィールドサイエン スセンター附帯施設農場に設置されており，バイオマスガ スを燃料として用い, 定格発電電力 $29 \mathrm{~kW}$ の MGT 発電シ ステムを基盤に, 最大発電電力 $100 \mathrm{~kW}$ の風力発電システ ム, そして, 風車からの变動電力を補償するための定格容量 $10 \mathrm{~kW}$ の FWES を 3 台用いたフライホイール電力補償シ ステム (以降 $\mathrm{FW}$ 電力補償システム) から構成される。 $\mathrm{FW}$ 電力補償システムは Fig. 2 に示すロータがフライホイール となった誘導機 3 台が 1 台のインバータに並列接続され制 御されている。また， $100 \mathrm{~kW}$ の風車は $29 \mathrm{~kW}$ の MGT 発 電システムに対する風車の規模を検討するために出力が大 きなものを設置した。

バイオマス発電が定常的に出力できる電力は事業所が定 常的に発生するバイオマスガス発生量に依存する。しかし, 提案システムでは，風力発電システムを複合することによ り, システム全体で定常的に出力できる電力を増やすことが でき，事務所のエネルギー自給率を上げることになる。ま た提案システムでは風力発電の電力変動を補償する FWES

FW compensation system

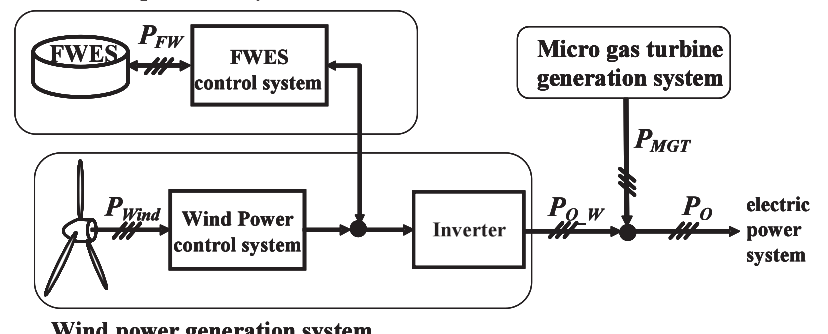

Fig. 1. Combined type natural energy generation system.

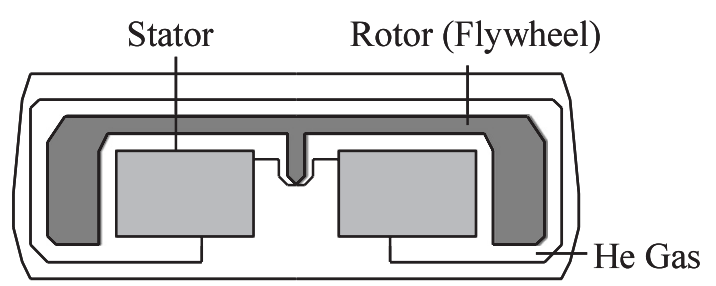

Fig. 2. Strcture of flywheel energy storage equipment.
を用いた補償システムを有している。FWES は風車の発電 電力の変動成分が平均電力よりも大きい場合は充電を行い, 小さい場合は放電をし, 変動電力の補償を行なっている。 一般的にFWES は直接, 三相系統に接続される。しかし提 案システムでは $\mathrm{FW}$ 電力補償システムを風力発電システム の直流リンクに並列に接続している。このような接続をす ることで系統連系インバータを 1 つにすることができる。 また，三相系統に接続した場合には風力発電システムの系 統連系インバー夕は風力発電機の最大発電電力以上の容量 を必要とするが，FWES を直流リンクで接続することで風 力発電システムの出力電力を平準化が可能となるため, 系 統連系インバータの容量を低減することが可能である。こ れらのことから, システム設計の際に要するコストの軽減 が可能である。

\section{3. 電力平準化制御}

高品質な電力供給を行なう場合には, 出力変動の抑制の ほかに, 高調波及び電圧変動の補償も考慮する必要がある。 しかし, 今回は出力変動の補償のみを考えるものとする。

風車からの発電電力 $P_{W i n d}$ の変動分にはさまざまな周波 数成分が含まれており, それらは風車の容量にも依存する が，ここでは平準化の手法を示すことに主眼をおいている ので，一例として $100 \mathrm{~kW}$ 風車の発電デー夕を基に行なう。 供給電力の平準化を行う際には, 風車からの変動的な発電 電力 $P_{\text {Wind }}$ の周波数特性を考慮に入れ, 高域. 中域・低域· 超低域の 4 つの周波数領域に周波数分離を行う。この概念 図を Fig. 3 に示す。このように周波数分離により得られた 中域成分 $P_{M}$ は FW 電力補償システムにより補償を行う周 波数成分である。また，低域成分 $P_{L}$ は MGT 発電システム により補償を行う周波数成分である。そして, Fig. 4 に示 すように，これらの正負を反転させ，両補償システムへの 電力補償指令值 $P_{F W_{-} r e f}$ 及び $P_{M G T \_r e f}$ を作成する。なお, MGT 発電システムへの電力指令值 $P_{M G T \_r e f}$ に関して, そ

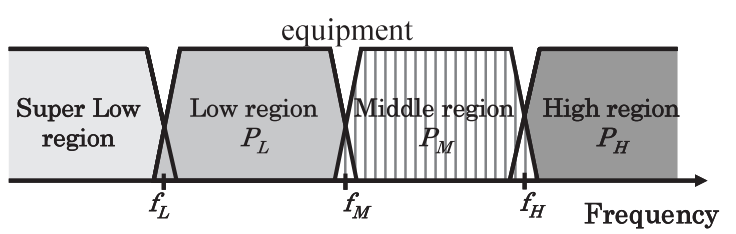

Fig. 3. Concept chart of frequency separation.

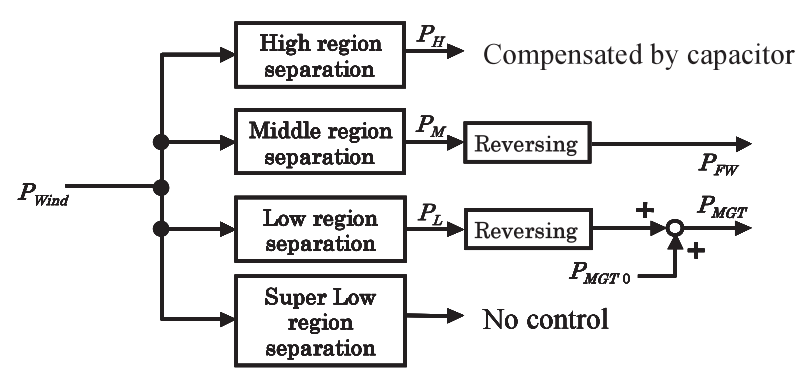

Fig. 4. Frequency separation method. 


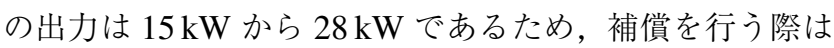
動作中心である $P_{M G T 0}(=21.5 \mathrm{~kW})$ を加える必要がある。 次に, 高域成分 $P_{H}$ とは FWES でも補償しきれない高周波 の成分を指す。そして，この成分の一部は，風力発電シス テムの電力変換器に付属される電解コンデンサによって補 償される。この電解コンデンサの容量の決定法については 第 5 章，6 章にて言及する。最後に，超低域成分とは数分 以上の非常にゆっくりとした周期で現れる成分であり，系 統に供給する変動として許容する成分とみなしている ${ }^{(5)}$ 。

\section{4. 補償システムの応答性による補償帯域の検討}

Fig. 3 のように風車から発電された電力を周波数分離す る際の 3 つの带域分離周波数 $f_{H}, f_{M}, f_{L}$ の決定は風車か ら発電された電力の周波数分布とその大きさだけでなく，2 つの補償システムの応答性と電力容量に依存する。ここで は，FW 電力補償システムと MGT 発電システムの応答性 を考慮した帯域分離周波数の決定法について述べる。

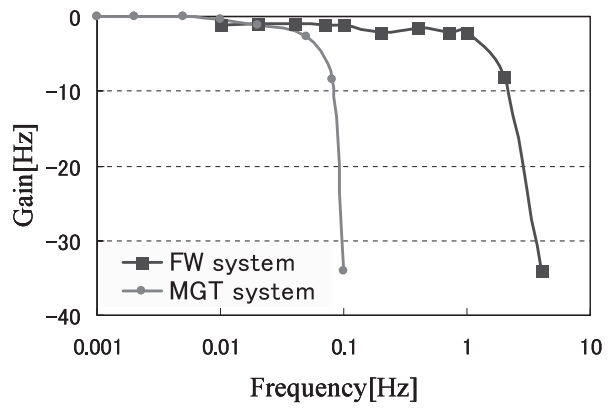

(a) Gain characteristic

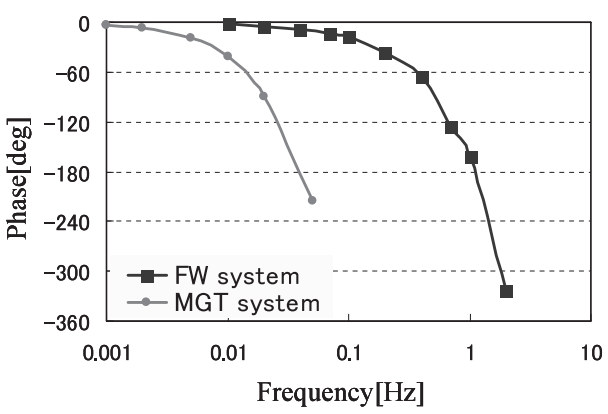

(b) Phase characteristic

Fig. 5. Frequency response result.
Fig. 5 は FW 電力補償システム及びMGT 発電システムに おいて測定した周波数特性である。周波数特性の測定は, 変 動電力の指令值の振幅をシステムへの影響が最も大きいと考 えられる, 許容変動電力範囲の最大值に設定して行なった。 Fig. 5(a)のゲイン特性結果から，FW 電力補償システムで は $1 \mathrm{~Hz}$ 程度まで, そして, MGT 発電システムでは $0.02 \mathrm{~Hz}$ 程度まで高いゲイン特性を得られることが分かる。しかし， Fig. 5(b) の位相特性結果からは, FW 電力補償システムで は約 $0.2 \mathrm{~Hz}$ ，そして，MGT 発電システムでは $0.01 \mathrm{~Hz}$ よ りも高い周波数において $30 \mathrm{deg}$ を超える大きな位相差が 生じている。ここで，三角演算を解いたとき，補償電力が $30 \mathrm{deg}$ 以上の遅れを生じるとその補償効果は半分以下とな る。そして，60 deg 以上の遅れが生じたときには反対に電 力脈動を増加させてしまう。したがって，带域分離周波数 を決定する際にはこれを考慮する必要があり，本システム では中域分離周波数 $f_{M}$ は MGT 発電システムの位相特性 が $30 \mathrm{deg}$ 以下である $0.01 \mathrm{~Hz}$ 以下に，そして，高域分離周 波数 $f_{H}$ は $\mathrm{FW}$ 電力補償システムの位相特性が $60 \mathrm{deg}$ 以下 である $0.4 \mathrm{~Hz}$ 未満に設定する必要がある。

\section{5. 電力容量による補償帯域の検討}

ここでは，風車の発電電力に含まれる周波数成分を基に FWES のエネルギー容量と MGT 発電機の稼働率を考慮し た帯域分離周波数の決定法を検討する ${ }^{(6)}$ 。

〈5・1〉 風力発電電力に含まれる周波数成分風車か ら発電される電力には多くの周波数成分が含まれる。Fig. 6 に三重大学構内に設置されている $100 \mathrm{~kW}$ の容量を持つ風 車から得られた発電結果を示す。この結果から, 今回測定 した風車から発電される電力に含まれる変動の主成分は約 $0.1 \mathrm{~Hz}$ 以下の変動成分であり，低周波の変動が多く含まれ ている。風車からの発電電力は変動が激しく季節により大 きく変動するものであるが，ここでは，Fig. 6 に示した発 電電力の一例を基に検討を始める。

今, Fig. 6 に示す風車から発電された電力を $0.001 \mathrm{~Hz}$ よ り高い変動成分を平準化すると仮定する。Fig.7(a) に補償 に必要な電力 $P_{C M P}$ を示し, Fig. 7(c) に $P_{C M P}$ を時間積分

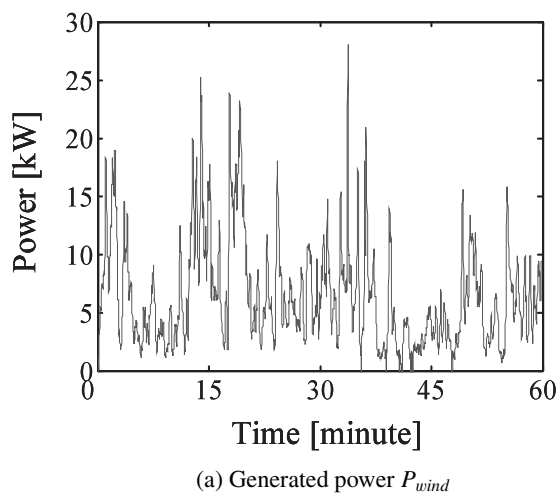

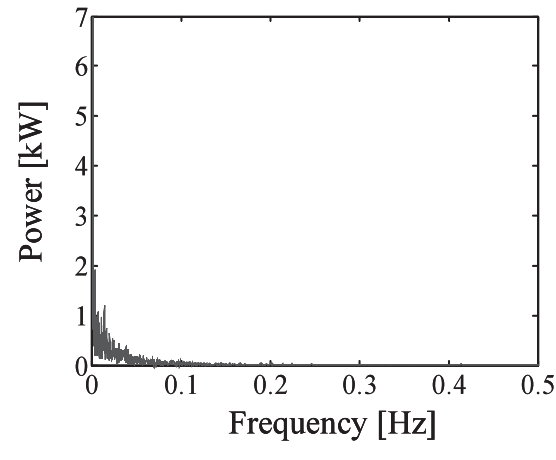

(b) Result of FFT (linear)

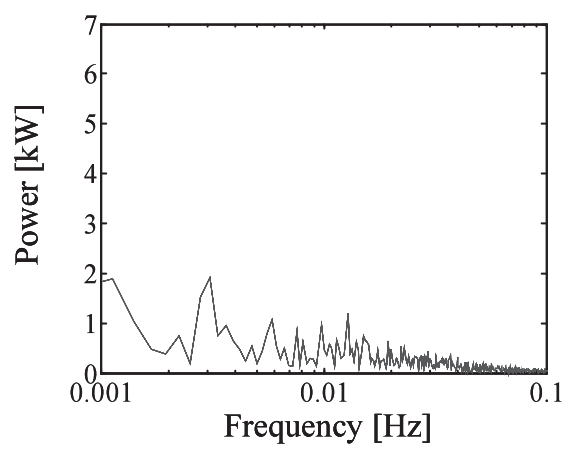

(c) Result of FFT (semi log)

Fig. 6. Generated power by wind power generation in campus. 


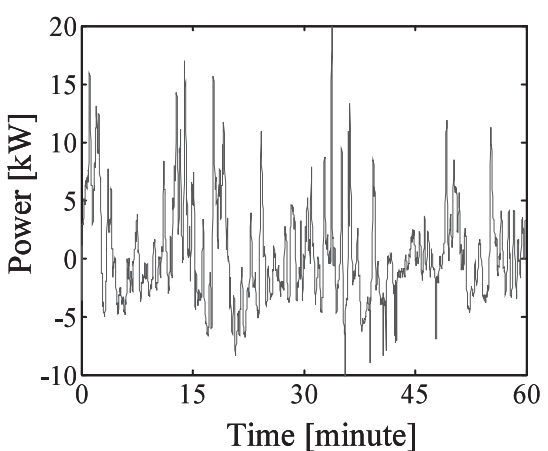

(a) Compensation region $P_{C M P}$

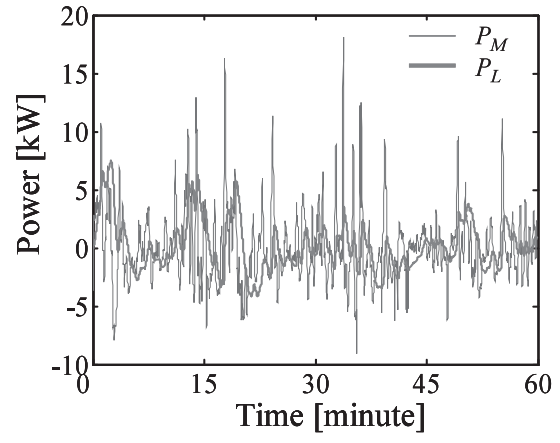

(b) Middle region $P_{M}$ and low region $P_{L}$

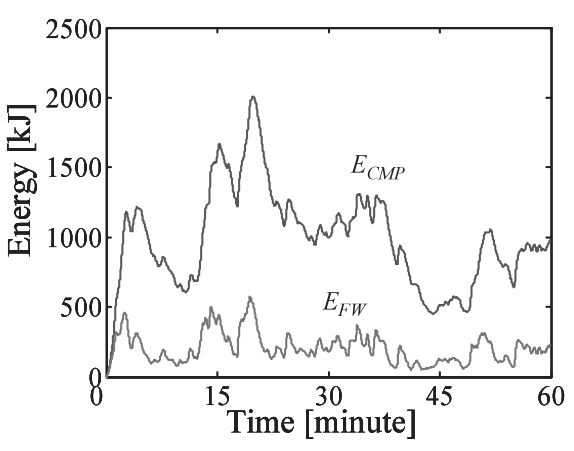

(c) Compensation energy

Fig. 7. Compensation power and energy.

し得られる補償エネルギー $E_{C M P}$ を示す。電力貯蔵装置の みで補償を行う際に，より低周波の変動成分まで補償しよ うとした場合には，必要とされる貯蔵装置の容量も大きく 設計しなければならない。しかし, 電力貯蔵装置で補償対 象とするすべての変動成分を補償するのではなく，補償対 象を中域成分 $P_{M}$ と低域成分 $P_{L}$ に分割し, 低域成分 $P_{L}$ を MGT 発電システムで補償することによって電力貯蔵装置 で補償に必要なエネルギーを低減することができると考え られる。

Fig. 7(b), (c) に補償対象とする $0.001 \mathrm{~Hz}$ よりも高い周波 数成分のうち $\mathrm{FW}$ 電力貯蔵装置で補償対象とする中域成分 $P_{M}$ と MGT 発電システムで補償対象とする低域成分 $P_{L}$ を 分離する中域分離周波数 $f_{M}$ を $0.005 \mathrm{~Hz}$ としたときの補償 成分と FW 電力貯蔵装置で補償に必要なエネルギーの変化 を示す。

Fig. 7(c) から MGT 発電システムで低域成分 $P_{L}$ を補償 することで, FWES で補償するエネルギー $E_{F W}$ の大きさ を最大で約 $1500 \mathrm{~kJ}$ 低減できていることが確認できる。ま た, 電力貯蔵装置は電力の蓄放電を行う装置であるため, 補 償エネルギーの大きさに制限を受ける。これに対し, MGT 発電システムは MGT 発電機による発電機構を有するため, 補償エネルギーに制限を受けない。このことから，提案シ ステムは，より低周波の変動成分まで電力補償を考えたと き，より有効な平準化システムであると考えられる。

〈5・2〉 マイクロガスタービン発電機の稼働率と電力変 換効率 MGT 発電システムでは定格発電電力 $29 \mathrm{~kW}$ の MGT 発電機を用い, 風力発電の低周波変動を補償するた め, 出力が $15 \mathrm{~kW}$ から $28 \mathrm{~kW}$ の間で可変に制御される。し かし, MGT 発電機の出力を変化させ, 稼働率の低い状態で 運転することは発電効率の低下を引き起こす。ここで, 稼 働率とは出力電力を定格出力電力で除算したときの商であ る。Fig. 8 に, 提案システムで用いる MGT 発電機におい て稼働率を変化させたときの発電効率の変化を示す。Fig. 8 から, MGT 発電機の出力を定格の $100 \%$ から $50 \%$ 変化 させると, 発電効率は $25.0 \%$ から $22.4 \%$ に低下しているこ とが分かる。したがって, MGT 発電機において, 高い電力 変換効率を得るためには高稼働率で運転する必要がある。

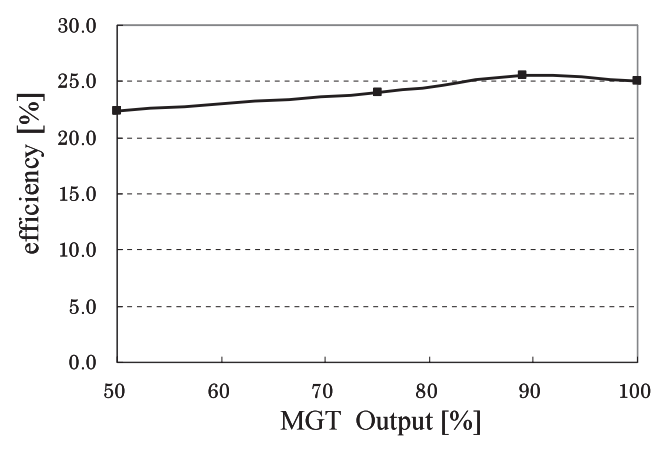

Fig. 8. Power conversion efficiency of MGT system.

また, MGT 発電機の稼働率の低下は MGT 発電システム で補償を行う低域成分 $P_{L}$ の変動幅で決定する。そして, 風 車から発電された電力をより低周波の变動成分まで補償す ることを考えたとき, 低域成分 $P_{L}$ の領域は拡大する。この ため, より, 低周波の変動を補償しようとした際には MGT 発電機の動作範囲を大きくとる必要がある。したがって, MGT 発電機の稼働率と補償可能な低周波成分はトレード オフの関係となる。このことから MGT 発電機の稼働率を 高く維持するためには低域分離周波数 $f_{L}$ を高く設定するこ とで系統に供給する際に許容する周波数帯域の高周波側へ の拡大する必要がある。

〈5・3〉 帯域分離周波数の変化によるマイクロガスター ビン発電機の稼働率とフライホイール電力貯蔵装置の容量 前述のように, 提案する複合型自然エネルギー発電シス テムでは風力発電の電力平準化を行うにあたり, $\mathrm{FW}$ 電力 貯蔵装置の補償エネルギーの大きさや, MGT 発電システ ムの稼働率を考慮する必要がある。そこで, Fig. 6(a)に示 す風車の発電電力を平準化する際に，2つの带域分離周波 数を変化させることで, $\mathrm{FW}$ 電力補償システムで中域成分 $P_{M}$ を補償する際に必要なエネルギー $\Delta E_{F W}$ 及び MGT 発 電機で補償対象とする低域成分 $P_{L}$ の変動幅 $\Delta P_{L}$ の大きさ がどのように変化するか確認した。この結果を Fig. 9 に示 す。なお, MGT 発電システム及び FW 電力補償システム の応答性を考慮したうえで, 低域分離周波数 $f_{L}$ を $0.002 \mathrm{~Hz}$ から $0.0005 \mathrm{~Hz}$ 間で変化させた。また, 中域分離周波数 $f_{M}$ 
に関しては $0.02 \mathrm{~Hz}$ から低域分離周波数 $f_{L}$ 付近の值まで変 化させた。そして, 低域成分 $P_{L}$ の変動幅 $\Delta P_{L}$ と中域成分 $P_{M}$ の補償に必要なエネルギー $\Delta E_{F W}$ は，(1) 式から (3) 式 で算出している。

$$
\begin{aligned}
& E_{F W}(t)=\int P_{M}(t) d t \ldots \ldots \ldots \ldots \ldots \\
& \Delta E_{F W}=\max \left(E_{F W}(t)\right)-\min \left(E_{F W}(t)\right) \\
& \Delta P_{L}=\max \left(P_{L}(t)\right)-\min \left(P_{L}(t)\right) \cdots \cdots
\end{aligned}
$$

Fig. 9(a)の結果から，FW 電力貯蔵装置で補償する際に 必要となるエネルギーの大きさ $\Delta E_{F W}$ は中域分離周波数 $f_{M}$ を低く設定することで，増加することが分かる。また， Fig. 9(b) から低域成分 $P_{L}$ の変動幅 $\Delta P_{L}$ の大きさは低域分 離周波数 $f_{L}$ の低下または中域分離周波数 $f_{M}$ の上昇により 大きくなることが分かる。したがって，システム設計の際 には, MGT 発電機システムの応答性に合わせ, 中域分離周 波数 $f_{M}$ を設定し, 中域成分 $P_{M}$ を補償するために必要な エネルギーの大きさから FWES の容量を決定する必要があ る。また, MGT 発電機の稼働率を考慮したうえで出力変 動幅を決定し，低域分離周波数及 $f_{L}$ を決定すればよい。

〈5・4〉 電解コンデンサによる高域成分の補償 本方式 は， $\mathrm{FW}$ 電力貯蔵装置で補償できない高域成分を風力発電 システムにおけるDCリンクの電力変換器に付属している 電解コンデンサで補償することを考えている。そのため，コ ンデンサ容量 $C$ も適切に設定する必要がある。この容量の 設定は高域成分 $P_{H}$ を補償するために必要なエネルギー容量 $\Delta E_{C}$ と, $\mathrm{DC}$ リン電圧を変動させる際の最大值 $V_{D C}$-max
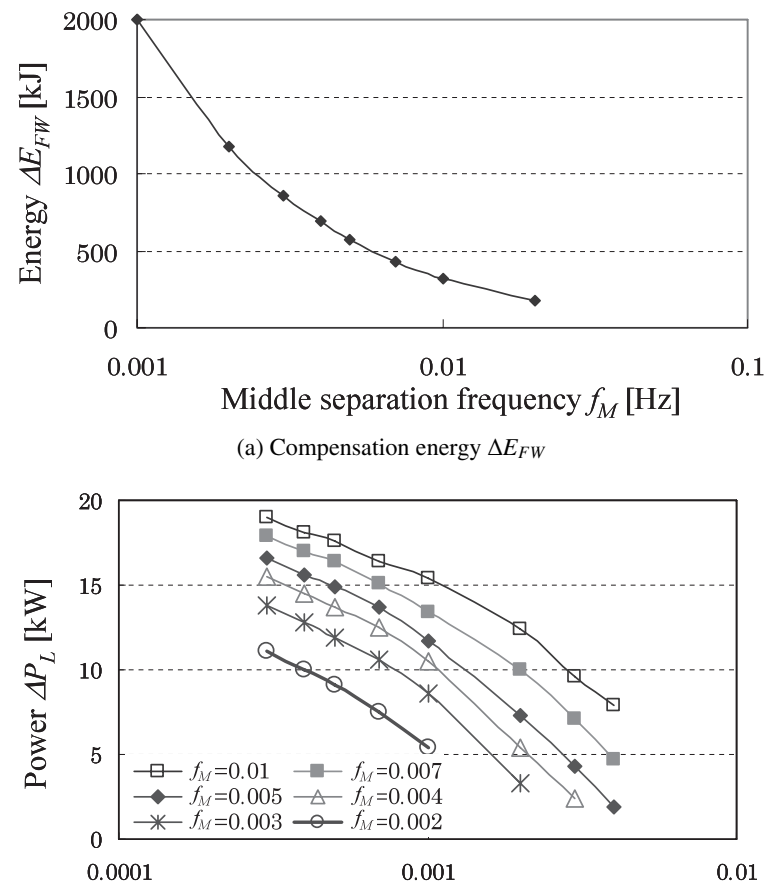

Low separation frequency $f_{L}[\mathrm{~Hz}]$

(b) Fluctuation power $\Delta P_{L}$

Fig. 9. Change in characteristic by separation frequency.
と最小值 $V_{D C \_ \text {min }}$ により決定する。したがって，(4) 式のよ うに決定すればよい。

$$
C=\frac{2 \cdot \Delta E_{C}}{V_{D C_{-} \max }^{2}-V_{D C_{-} \min }^{2}}
$$

また, 風車の発電電力の出力レベル及び周波数分布は大き く変動するため上記の検討は統計的に処理する必要がある。 しかし，検討の手法については有効であると考える。例え ば，発電電力の周波数分布が Fig. 5 とほぼ同様のものであ り, 発電電力の絶対量が 2 倍に増加した場合には, 単純に 中域成分 $P_{M}$ を補償する際に必要なエネルギー $\Delta E_{F W}$ 及び 低域成分 $P_{L}$ の変動幅 $\Delta P_{L}$ は 2 倍になると考えればよい。

\section{6. 実証実験}

前章では, 風車の発電電力に含まれる周波数成分と MGT 発電機の稼働率, FWES の貯蔵容量, そして, 電力品質を 考慮したFWES の容量決定法を示した。そして, 実証試験 システムでは MGT 発電機の変動幅を $13 \mathrm{~kW}$ とし, FWES としては最大補償容量 $900 \mathrm{~kJ}$ の装置を用いる。

提案システムの有効性を証明するために実証実験を行っ た。このとき，風車の発電電力を 4 つの周波数領域に分離 するための 3 つの帯域分離周波数を Table 1 に示し, 実験 結果を Fig. 10 に示す。なお, 帯域分離周波数 $f_{L}, f_{M}, f_{H}$ を前章で述べた考えを基にし，次のように決定した。

Fig. 5 から, MGT 発電システムで補償可能な周波数領域は $0.01 \mathrm{~Hz}$ 以下である。また, FWES の最大貯蔵容量は $900 \mathrm{~kJ}$ であるため, Fig. 9(a) から, 中域分離周波数 $f_{M}$ は $0.003 \mathrm{~Hz}$ 以下である必要がある。したがって, 貯蔵容量に対し余裕 を持たせ，中域分離周波数 $f_{M}$ は $0.005 \mathrm{~Hz}$ に設定した。次 に, Fig.9(b) において, 中域分離周波数 $f_{M}$ が $0.005 \mathrm{~Hz}$ の ときを考える。そして, MGT 発電機の動作変動幅を $13 \mathrm{~kW}$ としているため，これに対して余裕を持たせ，低域分離周 波数 $f_{L}$ を $0.001 \mathrm{~Hz}$ と設定する。最後に, 高域分離周波数 $f_{H}$ は FW 電力補償システムにおいて補償効果の期待できる 最大の周波数帯域である $0.3 \mathrm{~Hz}$ 程度に設定される必要があ る。しかし, 周波数分離は带域分離周波数をカットオフ周 波数とする 1 次のローパスフィルタを用いることで実現し ている。また, Fig. 6(b) から風車から発電される電力に含 まれる変動のうち, 主となる変動成分は $0.2 \mathrm{~Hz}$ 程度まで存 在している。そのため, 高域分離周波数を $0.3 \mathrm{~Hz}$ にしたと き,この $0.2 \mathrm{~Hz}$ 付近の補償信号は減衰する。しかし, $0.3 \mathrm{~Hz}$ 以上の変動は僅かであることから, 高域分離周波数 $f_{H}$ は $0.2 \mathrm{~Hz}$ の補償信号が減衰しないように $0.3 \mathrm{~Hz}$ よりも大きな 值に設定することが望ましいと考える。したがって，高域 分離周波数 $f_{H}$ は $2 \mathrm{~Hz}$ に設定する。Fig. 10 から, 風車単体

Table 1. Band separation frequency.

\begin{tabular}{|c|r|}
\hline$f_{H}$ & $2[\mathrm{~Hz}]$ \\
\hline$f_{M}$ & $0.005[\mathrm{~Hz}]$ \\
\hline$f_{L}$ & $0.001[\mathrm{~Hz}]$ \\
\hline
\end{tabular}




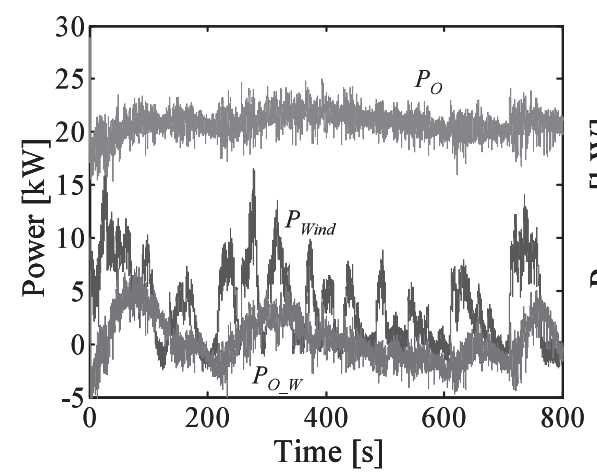

(a) Result of compensation power

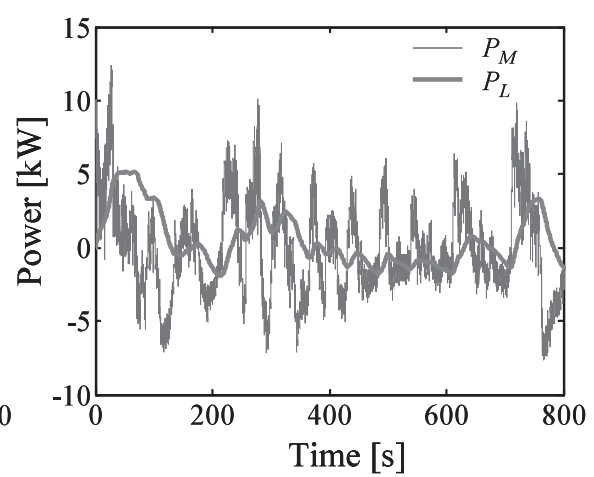

(b) $P_{M}$ and $P_{L}$

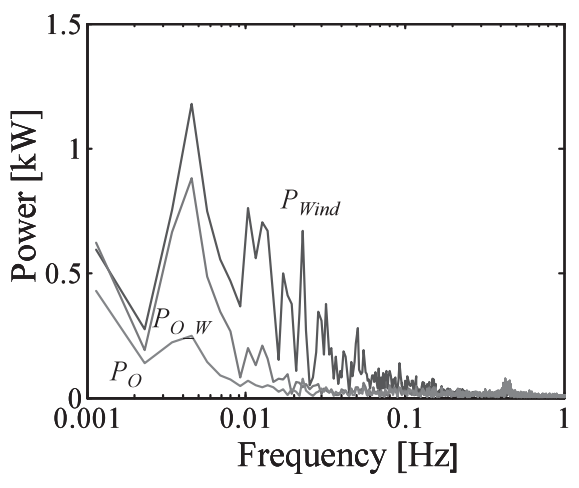

(c) Result of FFT

Fig. 10. Compensated result of power fluctuation.

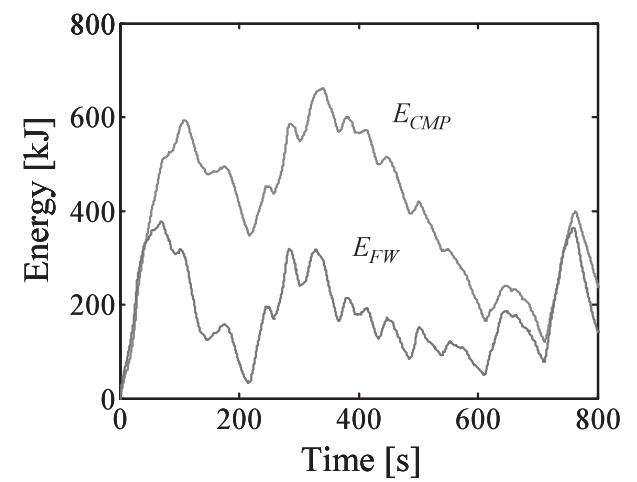

Fig. 11. Compensated energy.

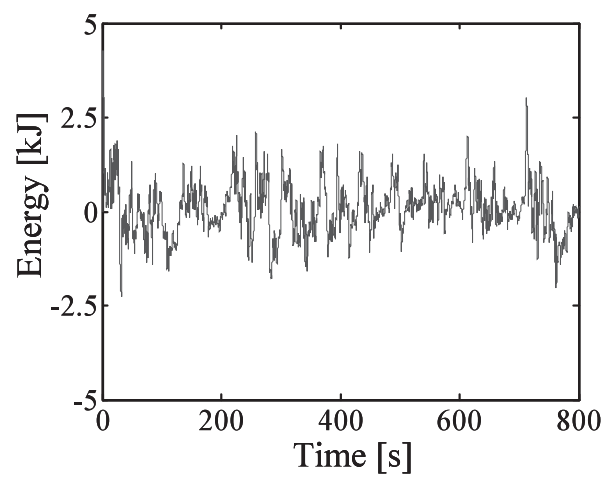

Fig. 12. Capacitor compensation energy.
からの発電電力 $P_{\text {Wind }}$ に対し, 風力発電システムと $\mathrm{FW}$ 電 力補償システムの合成電力を系統連系インバー夕により系 統に出力される電力 $P_{O_{-} W}$ は $\mathrm{FW}$ 電力補償システムを動作 させることにより, FW 電力補償システムの補償対象であ る $0.005 \mathrm{~Hz}$ よりも高い周波数成分を補償できていることが 分かる。次に, $P_{O_{-} W}$ に対し, 最終的な系統への出力 $P_{O}$ は MGT 発電システムを動作させることによって $0.005 \mathrm{~Hz}$ か ら $0.002 \mathrm{~Hz}$ 程度の変動成分を補償できていることが確認で きる。ここで, 風車の発電電力 $P_{\text {Wind }}$ に扔いて負となる領域 が存在している。これは, 本システムの風車では風力発電 機の回転数がある設定值よりも小さい場合, 電動機動作を することで，設定された回転数を維持するシステムとなっ ているためである。また，風力発電システムの出力 $P_{O_{-} W}$ の平均值が $P_{\text {Wind }}$ のそれよりも低下している。これは, FW 電力補償システム及び風力発電システムに打ける電力変換 器で生じる損失や, FWES に扔いて生じる風損, 銅損などの 損失を発電電力 $P_{\text {Wind }}$ でまかなっているためである。本研 究では電力脈動に観点を扔いているため出力の平均值が負 となっていることは問題にならないと考える。このような 状況下で MGT 発電システムによって電力脈動の低周波成 分を補償することにより $\mathrm{FW}$ 電力補償システムで補償する エネルギーをどの程度軽減できるかを確認した。この結果 を Fig. 11 に示す。Fig. 11 から, 今回行った実験に扔いて, 補償に必要とした全エネルギー $E_{C M P}$ の最大值は約 $700 \mathrm{~kJ}$ であるのに対して，FW 電力補償システムで補償したエネ
ルギー $E_{F W}$ の最大值は約 $400 \mathrm{~kJ}$ であることがわかる。こ れより, MGT 発電システムにより FW 電力補償システムで 補償するエネルギーを約 $300 \mathrm{~kJ}$ 軽減できていることから， 提案システムの有効性を確認できたと考える。

また，本実験において FW 電力補償システムで補償でき なかった高周波成分をキャパシタで補償する際に必要な補 償エネルギーの推移を Fig. 12 示す。この結果から補償に 必要なエネルギー容量は約, $5 \mathrm{~kJ}$ である。この場合, 本シ ステムは風力発電システムの DC リンク電圧を $650 \mathrm{~V}$ から $710 \mathrm{~V}$ の間で変化させる。(4) 式から, 約 $125 \mathrm{mF}$ の容量を 有したキャパシタを用意すればよいことになる。ただし， $\mathrm{FW}$ 電力補償システムの応答性を考えると改善の必要があ る。そして, 高域分離周波数 $f_{H}$ を高くすることで，キャ パシタで補償すべき高周波成分が低減されるため, 必要な キャパシ夕容量は低減される。

\section{7. まとめ}

本論文では, 風力発電から発電される脈動電力を高域 · 中域・低域に分離し, 低域成分をバイオマスガスタービン 発電機で, 中域成分をフライホイール電力貯蔵装置で補償 する電力補償法を提案した。そして，マイクロガスタービ ン発電機で低域成分を補償することでフライホイール電力 貯蔵装置が補償すべき電力容量を低減できることを明らか にした。しかし，フライホイール電力貯蔵装置の応答性の 改善によりキャパシ夕に要求される容量を低減できること 
を示した。今後の課題としては，バイオマス発電の応答性 と規模を考慮したシステムの構築，負荷変動や高調波を考 慮にいれた系統連系インバータの制御法の検討などがある。 (平成 19 年 1 月 4 日受付，平成 19 年 6 月 22 日再受付)

\section{文献}

(1) K. Kiichiro: "The Present Situation and Problem Area of Waste to Energy and Biomass Energy", Energy \& Resources, Vol.27, No.3, pp.6-10 (2006-3) (in Japanese)

小川紀一郎：「廃棄物発電とバイオマスエネルギーの利用の現状課 題」, エネルギー・資源, 27, 3, pp.6-10 (2006-3)

(2) A. Koyanagi, H. Nakamura, Y. Suzuki, M. Molinas, and R. Shimada: "Study on Power Fluctuation Compensation of Wind Turbin Generator by Flywheel", 2000 National Convention Record IEE Japan, Industry Application Society, Vol.2, T-67, p.715 (2000) (in Japanese)

小柳明大・中村浩和・鈴木康慎・マルタモリナス・嶋田隆一：「可変 速フライホイール発電機による風力発電変動補」, 平成 12 年電気学 会産業応用部門大会, T-67, p.715 (2000)

(3) R. Takahashi, L. Wu, T. Murata, and J. Tamura: "An Application of Flywheel Energy Strage System for Wind Energy Conversion”, IEEE PEDS, pp.932-937 (2005)

(4) K. Masahide, H. Kashihara, A. Hirokawa, and T. Watanebe: "Development of Recuperated Gas Turbine for Biomass Pressurized Fluidized Bed Gasification System", The 10th National Symposium on Power and Energy Systems (SPE 2005), pp.227-230 (2005)

(5) M. Hara, T. Matsukawa N. Yamamura, M. Ishida, M. Wakita, Y. Kamada, and T. Maeda: "Proposal of Low Frequency Power Compensation Method of Wind Power Generation Using Biomass Gas Turbine Generator", The Papers of Joint Technical Meeting on PE, PSE and SPC, IEE Japan, pp.1317 (2006) (in Japanese)

原 真彦 · 松川達哉 · 山村直紀 · 石田宗秋 ·脇田正彰 ·鎌田泰成 · 前田太佳夫：「バイオマスガスタービン発電機を用いた風力発電の 低周波変動補償法の提案」, 電気学会電力技術 - 電力系統技術 - 半導 体電力変換研資, pp.13-17 (2006)

(6) M. Hara, N. Yamamura, M. Ishida, M. Wakita, Y. Kamada, and T. Maeda "Method of Electric Power Compensation for Wind Power Generation Using Biomass Gas Turbine Generator and Flywheel—One Study For Electric Power Capacity_-", The Papers of Joint Technical Meeting on EE, IEICE Japan, pp.59-64 (2006) (in Japanese)

原 真彦・山村直紀·石田宗秋・脇田正彰·鎌田泰成·前田太佳夫：「八 イオマスガスタービンとフライホイールを用いた風力発電の電力補 償法」, 電気情報通信学会電子通信エネルギー技術研究報告, pp.59-64 (2006)

真 彦 (学生員) 1983 年 1 月 9 日生。 2007 年 3 月三重

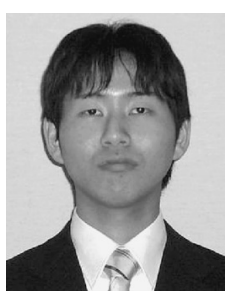
大学大学院工学研究科博士前期課程電気電子工学 専攻修了。同年 4 月シャープ (株) 入社。

山 村 直 紀 （正員） 1964 年 10 月 20 日生。1993 年 3 月名 古屋工業大学大学院博士後期課程電気情報工学専 攻修了。同年 4 月名古屋工業大学電気情報工学科 助手。1998 年 4 月三重大学工学部電気電子工学 科講師。工学博士。インバータを用いた電動機駆 動・発電システム, アクティブフィル夕の開発に 従事。IEEE，パワーエレクトロニクス学会会員。
石 田 宗 秋 (正員) 1952 年 4 月 12 日生。1 980 年 3 月名古

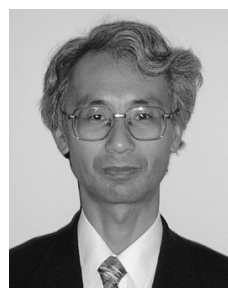
屋大学大学院工学研究科電気工学拈よび電子工学 専攻博士後期課程修了。同年 4 月同大学工学部電 気工学科助手。1987 年 6 月三重大学工学部電気 電子工学科助教授, 1996 年 10 月同大学工学部電 気電子工学科教授, 現在に至る。工学博士。1993, 2001 年電気学会論文賞, 1999 年電気学会著作賞受 賞, 2002 年計測自動制御学会論文賞受賞。IEEE, パワーエレクトロニクス学会, 計測自動制御, 日本機械学会, 溶接学 会会員。

脇 田 正 影 (非会員) 1945 年 6 月 10 日生。1 1970 年 3 月三

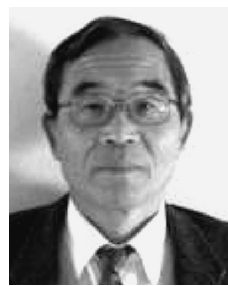
重大学大学院農学研究科修士課程修了。同年 4 月 三重大学農学部農学科助手, 1981 年 12 月同大学 農学部農学科助教授, 1987 年 10 月同大学生物資 源学部生物資源学科助教授, 1998 年 11 月同大学 生物資源学部生物資源学科教授, 2000 年同大学生 物資源学部生物圈生命科学科教授, 現在に至る。 農学博士。家畜の栄養，成長，管理に関する研究 に従事。日本畜産学会, 日本家禽学会, 日本比較内分泌学会会員。

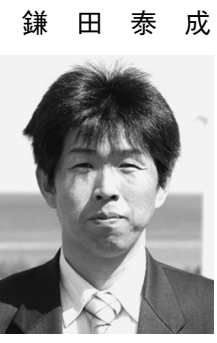

(非会員) 1968 年 11 月 2 日生。 1994 年 3 月三重 大学大学院工学研究科修士課程修了。同年 4 月同 大学工学部機械工学科助手, 2007 年 1 月同大学大 学院機械専攻助教授, 2007 年 4 月同大学工学部機 械工学科准教授, 現在に至る。工学博士。2000 年 Wind Power for the 21st Century Poster Award, 2004 年および 2006 年 2004 年論文ポスター賞（日本風 力エネルギー協会), 2005 年 EXPO WCWRF 2005 Poster Award 受賞。日本機械学会, 風力エネルギー協会, ヨーロッパ 風力エネルギー協会, ターボ機械協会会員。

前 田 太佳夫 (非会員) 1991 年 3 月名古屋大学大学院工学研

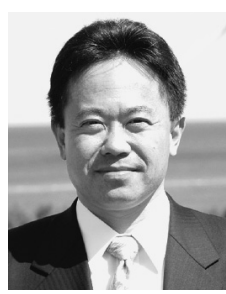
究科博士課程後期課程機械工学及び機械工学第二 専攻満了。同年 4 月名古屋大学工学部助手。1 1995 年 6 月オランダ王国デルフト工科大学風力エネル ギー研究所フェローシップ研究員。1997 年 1 月 三重大学工学部助教授, 2005 年 12 月同大学工学 部教授，2006 年 4 月同大学大学院工学研究科教 授, 現在に至る。工学博士。日本機械学会, 日本 風力エネルギー協会理事, ターボ機械協会, 日本風力発電協会顧問。 